\title{
PENGARUH KARAKTERISTIK PETERNAK MELALUI KOMPETENSI PETERNAK TERHADAP KINERJA USAHA TERNAK SAPI POTONG DI KABUPATEN BANDUNG
}

\author{
Diyani Fauziyah ${ }^{1}$, Rita Nurmalina ${ }^{2}$, dan Burhanuddin ${ }^{2}$ \\ 1)Mahasiswa Pascasarjana Magister Sains Agribisnis, Departemen Agribisnis \\ Fakultas Ekonomi dan Manajemen, Institut Pertanian Bogor \\ 2)Staf Pengajar Departemen Agribisnis, Fakultas Ekonomi dan Manajemen, Institut Pertanian Bogor \\ e-mail : 1)diyani.fauziyah@yahoo.com
}

\begin{abstract}
This research aims to: (1) identify characteristics and competencies of beef cattle farmer, and (2) analyze the influence of characteristics through competencies of farmer on business performance of beef cattle farm in Bandung Regency. In this research, the farmer characteristics consist of personal and psychological characteristic, whereas the competencies consist of technical and entrepreneurial competency. This research used 121 data of beef cattle farmers that collected by proportional cluster sampling according to the central areas of the farm, namely Cikancung, Cimenyan, and Cimaung Districts. The data were analyzed by SEM (Structural Equation Modeling) analysis. The results showed that both characteristics positively and significantly influence both competencies, and also have an indirect effect on business performance by technical competency. Psychological characteristic (need for achievement as a strong predictor) more influential on competencies than personal characteristic (informal education as a strong predictor). Technical competency (managing marketing and input as a strong predictor) positively $(\gamma=0.81)$ and significantly influence the business performance (productivity as a strong predictor), while the influence of entrepreneurial competency is not significant. Indirectly, psychological characteristic (0.56) more influential on business performance than personal characteristic (0.29). The implication, beef cattle productivity can be increased by improving technical competency, especially for managing marketing and input. This competency can be improved by increasing need for achievement and active participation of farmers in attending the counseling/training by giving them rewards.
\end{abstract}

Keywords: beef cattle farm, business performance, characteristics, competencies, entrepreneurial competencies.

\section{PENDAHULUAN}

Di akhir tahun 2015, Indonesia akan menghadapi persaingan global di wilayah regional ASEAN yang dikenal dengan AEC (ASEAN Economic Community) atau MEA (Masyarakat Ekonomi ASEAN). Kesepakatan ini menuntut kemandirian pelaku usaha karena intervensi pemerintah harus lebih diminimalisir. Sumardjo (1999) menegaskan bahwa petani dituntut untuk memiliki aspirasi, kreatif, inovatif, mampu mengambil keputusan yang menguntungkan, dan tangguh dalam beragribisnis, tidak lagi mengandalkan proteksi dan subsidi dari pemerintah. Jadi, petani kecil pada perkembangan ekonomi saat ini tidak hanya dituntut untuk memiliki kompetensi teknis, tetapi juga kompetensi manajerial dan kewirausahaan (Bergevoet 2005).

Sebagai salah satu subsektor pertanian, peternakan berperan penting dalam penyediaan bahan pangan, terutama dalam pemenuhan protein hewani bagi masyarakat. Daging sapi merupakan salah satu pangan strategis dari hasil peternakan yang menjadi target swasembada. Namun, produksinya masih belum dapat memenuhi kebutuhan dalam negeri, dimana neraca kebutuhan dan ketersediaan daging sapi di tahun 2012 mengalami defisit produksi sebesar 21.46 28.06 persen (Direktorat Pangan dan Pertanian 2013). Hal ini menyebabkan tingkat ketergantungan pada impor masih sangat tinggi. 


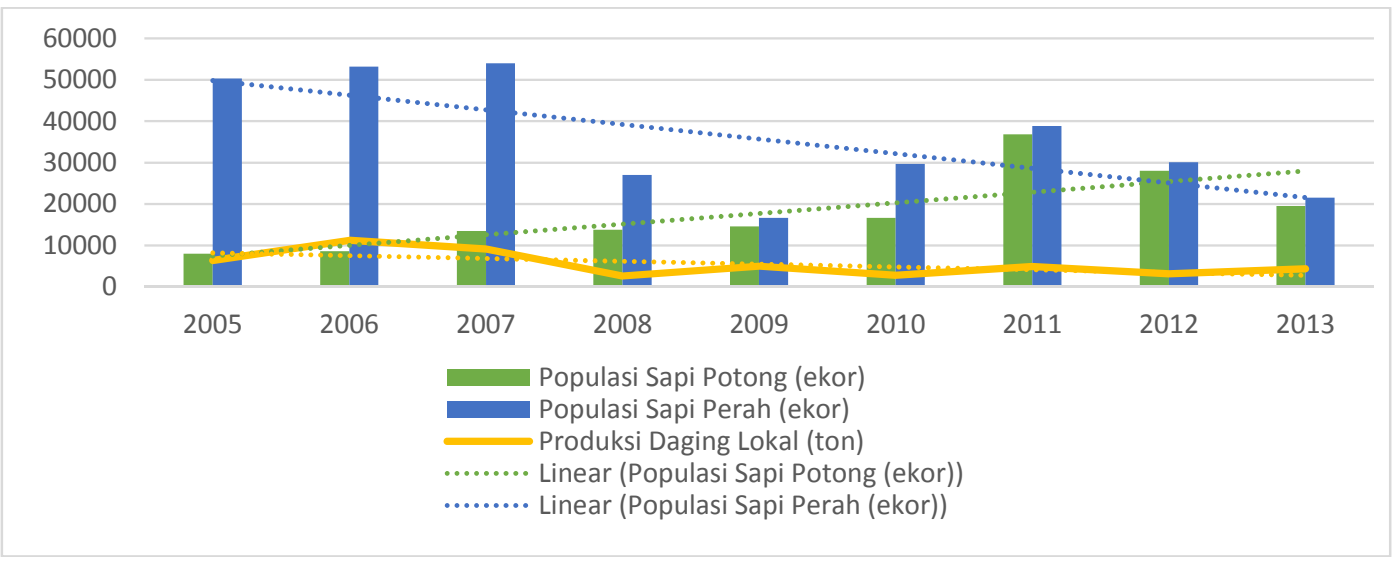

\section{Gambar 1. Trend Perkembangan Populasi Sapi dan Produksi Daging Sapi Lokal di Kabupaten Bandung tahun 2005-2013 \\ Sumber: Dinas Peternakan Provinsi Jawa Barat 2009 dan 2013 (diolah)}

Dua prinsip utama program swasembada daging sapi di dalam Permentan No. 19/Permentan/OT.140/2/2010 menekankan pada kinerja usaha ternak dalam negeri dan kompetensi peternak yang dinilai rendah. Oleh karena itu, kompetensi peternak dan kinerja usaha ternak sapi potong, serta karakteristik peternak yang diduga mempengaruhi kompetensi menjadi menarik untuk diteliti.

Kabupaten Bandung memiliki banyak komoditi unggulan dari sektor pertanian. Salah satu komoditas unggulan subsektor peternakan adalah sapi perah. Uniknya, data tersebut mengklasifikasikan sapi jantan jenis FH (Fries Holland) ke dalam komoditas sapi perah, padahal para peternak justru menjadikan sapi jenis ini sebagai salah satu komoditas sapi potong. Selain itu, dari hasil observasi diketahui bahwa peternak sapi di Kabupaten Bandung mulai beralih pada usaha ternak sapi potong. Data dari Dinas Peternakan Provinsi Jawa Barat tahun 20052013 membuktikan bahwa rata-rata laju perkembangan populasi sapi potong di Kabupaten Bandung cenderung meningkat, sedangkan sapi perah cenderung menurun. Namun, produksi daging sapi lokal setiap tahunnya juga cenderung menurun. Kecende- rungan ini diduga karena peternak belum memiliki kompetensi dalam usaha ternak sapi potong terutama dari segi produksi dan pemasaran produk yang berbeda dengan usaha ternak sapi perah.

Oleh karena itu, tujuan dari penelitian ini adalah: (1) mengidentifikasi karakteristik dan kompetensi peternak sapi potong, dan (2) menganalisis pengaruh karakteristik peternak melalui kompetensinya terhadap kinerja usaha ternak sapi potong di Kabupaten Bandung.

\section{KERANGKA PEMIKIRAN}

\section{KARAKTERISTIK INDIVIDU}

Tinggi rendahnya kompetensi dan kinerja usaha selalu dikaitkan dengan karakteristik individu SDM-nya. Mengacu pada model SEM Bergevoet (2005), maka karakteristik individu dapat dibagi menjadi karaktersitik personal dan psikologis. Karakteristik personal di antaranya meliputi usia, pendidikan, pengalaman (Lionberger dan Gwin 1982, Bird 1996, Riyanti 2003, Alma 2010), dan kekosmopolitan (Lionberger 1960). Sementara karakteristik psikologis di antaranya meliputi motivasi (Bird 1996) dan kebutuhan berprestasi (Sorensen dan Chang $2006)^{3}$.

\footnotetext{
${ }^{3}$ Teori McClelland menyebutkan 3 kebutuhan yaitu: n'ach (kebutuhan berprestasi), n'pow (kebutuhan kekuasaan), dan n'aff (kebutuhan hubungan). Namun, hasil review literatur Sorensen dan Chang (2006) menyatakan bahwa faktor psikologis yang berpengaruh terhadap kesuksesan wirausaha adalah n'ach (kebutuhan berprestasi).
} 
Menurut Alma (2010), umumnya seorang wirausaha berusia 22-55 tahun. Memulai usaha di luar usia ini seseorang dapat dimungkinkan kurang pengalaman atau terlambat melangkah. Padmowihardjo (1994) menyatakan, setelah mencapai usia 55 atau 60 tahun, kemampuan belajar dan berpengalaman semakin berkurang. Hal ini berarti bahwa umur mempengaruhi kompetensi dan kinerja peternak.

Menurut Riyanti (2003), pendidikan merupakan salah satu faktor yang menunjang keberhasilan usaha skala kecil, dengan asumsi semakin tinggi tingkat pendidikan, semakin baik pengetahuannya dalam mengelola usaha. Menurut Alma (2010), tingkat pendidikan yang memadai penting bagi wirausaha, terutama dalam menjaga kontinuitas usaha dan mengatasi masalah yang dihadapi.

Pendidikan informal (penyuluhan/ pelatihan), dapat mempermudah peternak dalam menerima informasi untuk meningkatkan kompetensi (Kartasapoetra 1987). Bergevoet (2005) menganalisis hubungan antara kompetensi kewirausahaan dengan karakteristik peternak sapi perah dan usaha ternaknya. Untuk meningkatkan kompetensi kewirausahaan peternak, program pelatihan perlu dirancang dan diberikan.

Kekosmopolitan adalah keterbukaan akses peternak terhadap informasi, melalui hubungan dengan berbagai sumber informasi dalam rangka mengembangkan usahanya. Lionberger (1960) menyatakan bahwa golongan masyarakat yang aktif mencari informasi dan ide-ide baru biasanya lebih inovatif dibandingkan dengan orang-orang yang pasif dan tidak percaya terhadap sesuatu yang baru. Hal ini menunjukkan bahwa tingkat kekosmopolitan peternak dapat mempengaruhi tingkat kompetensi kewirausahaannya.

Motivasi adalah dorongan yang menyebabkan seseorang mulai menjalankan usahanya. Inggarwati dan Kaudin (2010) berasumsi bahwa wirausaha yang memulai usahanya dengan motivasi yang kuat akan memiliki keinginan yang lebih tinggi untuk mengembangkan usahanya. Adapun faktor utama yang memotivasi seseorang untuk memulai usahanya dikelompokkan ke dalam faktor pendorong (push factor) dan penarik (pull factor). Usaha-usaha yang dimulai karena faktor pendorong secara finansial kurang berhasil jika dibandingkan dengan faktor penarik (Amit dan Muller 1995).

Kebutuhan berprestasi (need for achievement) adalah suatu nilai sosial yang menekankan pada hasrat untuk mencapai hasil terbaik untuk mencapai kepuasan pribadi yang harus dipenuhi (Suhandana 1980 dalam Suryana 2013).

\section{KONSEP KOMPETENSI}

Konsep kompetensi menurut Spencer dan Spencer (1993) bahwa: "A competency is an underlying characteristic of an individual that is causally related to criterion-referenced effective and/or superior performance in a job situation."

Underlying characteristic berarti bahwa kompetensi merupakan bagian yang paling melekat di dalam kepribadian seseorang dan dapat memprediksi perilaku dalam berbagai macam situasi dan tugas. Berkaitan dengan hal ini, Spencer dan Spencer menyebutkan lima komponen kompetensi, yaitu motif, sifat, konsep diri, pengetahuan, dan keterampilan.

Causally related bermakna bahwa ketiga kompetensi tersebut (motif, sifat, dan konsep diri) mampu memprediksi perilaku yang menampilkan keterampilan seseorang yang selanjutnya dapat memprediksi kinerja. Artinya, jika mempunyai kompetensi yang tinggi, maka akan memiliki kinerja yang tinggi pula (Moeheriono 2009). Dijelaskan pula bahwa di dalam kompetensi selalu disertakan motif yang menyebabkan seseorang bertindak untuk mencapai tujuan atau hasil akhir.

Criterion-referenced berarti bahwa kompetensi sebenarnya dapat memprediksi baikburuknya kinerja seseorang yang diukur dengan kriteria-kriteria khusus atau standar tertentu. 


\section{KONSEP KEWIRAUSAHAAN}

Menurut Griffin (2004) kewirausahaan adalah proses perencanaan, pengorganisasian, pengoperasian, dan pengambilan risiko dari suatu usaha bisnis. Sementara menurut Suryana (2013), kewirausahaan merupakan kemampuan kreatif dan inovatif yang dijadikan dasar, kiat, dan sumber daya, untuk menciptakan peluang agar meraih kesuksesan usaha atau hidup. Secara sederhana, kreatif dapat diartikan sebagai memikirkan sesuatu yang baru (thinking new things), sedangkan inovatif dapat diartikan sebagai melakukan sesuatu yang baru (doing new things) (Levitt dalam Zimmerer dan Scarborough 1996).

\section{KOMPETENSI PETANI WIRAUSAHA}

Pada model SEM Bergevoet (2005), kompetensi petani dibagi menjadi kompetensi teknis, manajerial dan kewirausahaan. Namun, beberapa penelitian di bidang kewirausahaan membedakan antara kompetensi manajerial dan kewirausahaan (Man et al. 2002, Lerner dan Almor 2002, Chandler dan Hanks 1994). Kompetensi kewirausahaan merupakan prasyarat untuk memulai suatu usaha, sedangkan kompetensi manajerial merupakan prasyarat untuk mengembangkan bisnis (Man et al. 2002). Kenyataan di lapangan menunjukkan bahwa peternak rakyat pada umumnya berpola pikir subsisten, bukan komersial (bisnis). Hal tersebut menjadi dasar bahwa dalam penelitian ini hanya mengkaji kompetensi teknis dan kewirausahaan yang dimiliki peternak untuk memulai suatu bisnis.

Sebagai seorang wirausaha, tentunya petani harus memiliki kompetensi yang tinggi karena seorang petani wirausaha juga merupakan petani yang unggul di bidangnya. Kompetensi teknis yang paling utama dibutuhkan adalah dalam pengelolaan input, produksi, dan pemasaran. Menurut Kahan (2012), yang paling membedakan petani wirausaha dengan petani lainnya dilihat dari perilaku mereka dalam mengelola ketiga aspek tadi, yaitu mereka selalu mencari cara terbaik dan memiliki kemauan untuk bereksperimen dalam usahanya.

Bird (1995) mendefinisikan kompetensi kewirausahaan sebagai karakteristik yang mendasari seperti pengetahuan khusus, motif, sifat, gambar diri, peran sosial dan keterampilan dalam menciptakan usaha baru, kelangsungan atau pertumbuhan usaha. Dengan kata lain, kompetensi kewirausahaan secara langsung mempengaruhi tingkat keberhasilan usaha.

Kahan (2012) mengemukakan bahwa petani wirausaha perlu memiliki kompetensi kewirausahaan yang terdiri atas inisiatif, ambisi, fokus pada pemecahan masalah, berpikir kreatif, mengambil risiko, fleksibilitas dan kemampuan beradaptasi, kemampuan interpersonal, jaringan, dan kesiapan belajar. Adapun komponen kompetensi tersebut terdiri atas pengetahuan (knowledge), keterampilan (skill), dan perilaku (behavior).

\section{KINERJA USAHA}

Kinerja usaha merupakan gambaran mengenai tingkat pencapaian pelaksanaan suatu program kegiatan dalam mewujudkan sasaran, tujuan, visi, dan misi organisasi yang dituangkan melalui perencanaan strategis suatu organisasi (Moeheriono 2009). Adapun kriteria kinerja usaha di antaranya adalah keberlangsungan usaha dan pertumbuhan usaha (Praag 2005, Riyanti 2003), keuntungan (Jauch dan Glueck 1998, dan produktivitas (Salman dan Badr 2011).

Keberlangsungan dan pertumbuhan usaha menunjukkan ketahanan suatu usaha dalam berproduksi. Keuntungan usaha adalah selisih antara penerimaan penjualan dan biaya yang dikeluarkan untuk menghasilkan suatu produk/jasa. Produktivitas diukur melalui perubahan output (produk) terhadap perubahan semua faktor input (modal dan tenaga kerja). Semakin tinggi kemampuan/kompetensi kewirausahaan seseorang, maka akan semakin meningkatkan produktivitas usaha yang dilakukan (Salman dan Badr 2011). 


\section{METODE PENELITIAN} LOKASI DAN WAKTU PENELITIAN

Penelitian ini dilakukan di 3 daerah sentra sapi potong di Kabupaten Bandung, yaitu Kecamatan Cikancung, Cimenyan, dan Cimaung pada bulan Agustus 2014 hingga Maret 2015.

\section{METODE PENGAMBILAN SAMPEL}

Populasi penelitian ini adalah peternak sapi potong di Kabupaten Bandung. Sampel penelitian dipilih secara purposive, yaitu di 3 kecamatan sentra sapi potong di Kabupaten Bandung.

Jumlah sampel dalam analisis SEM paling sedikit lima kali jumlah indikator yang digunakan. Adapun jumlah indikator yang digunakan dalam penelitian ada 23 , sehingga jumlah sampel yang dibutuhkan minimal adalah $23 \times 5=115$ responden.

Dalam penelitian ini, diambil 121 responden peternak sehingga sudah memenuhi jumlah sampel yang disyaratkan. Untuk penetapan jumlah responden dari masing-masing kecamatan digunakan teknik proportional cluster sampling.

\section{VARIABEL PENELITIAN DAN SKALA PENGUKURAN}

Variabel penelitian dalam model persamaan struktural (SEM) terdiri atas variabel laten dan variabel manifest. Variabel laten terdiri atas variabel laten eksogen dan endogen. Variabel manifest pada kuesioner penelitian diukur menggunakan skala Likert yang terbagi menjadi lima skala/skor. Semakin tinggi skor yang diperoleh, penilaian terhadap suatu objek semakin positif, demikian sebaliknya.

\section{METODE ANALISIS DATA}

Data kuisioner direkapitulasi dengan menggunakan program MS Excel 2013 . Hasil olahan selanjutnya menjadi input dan dianalisis menggunakan metode SEM dengan bantuan program LISREL 8.72 untuk menguji pengaruh karakteristik peternak melalui kompetensinya terhadap kinerja usaha ternak sapi di Kabupaten Bandung.

Tabel 1. Variabel Laten dan Indikator/Manifest Model Persaman Struktural

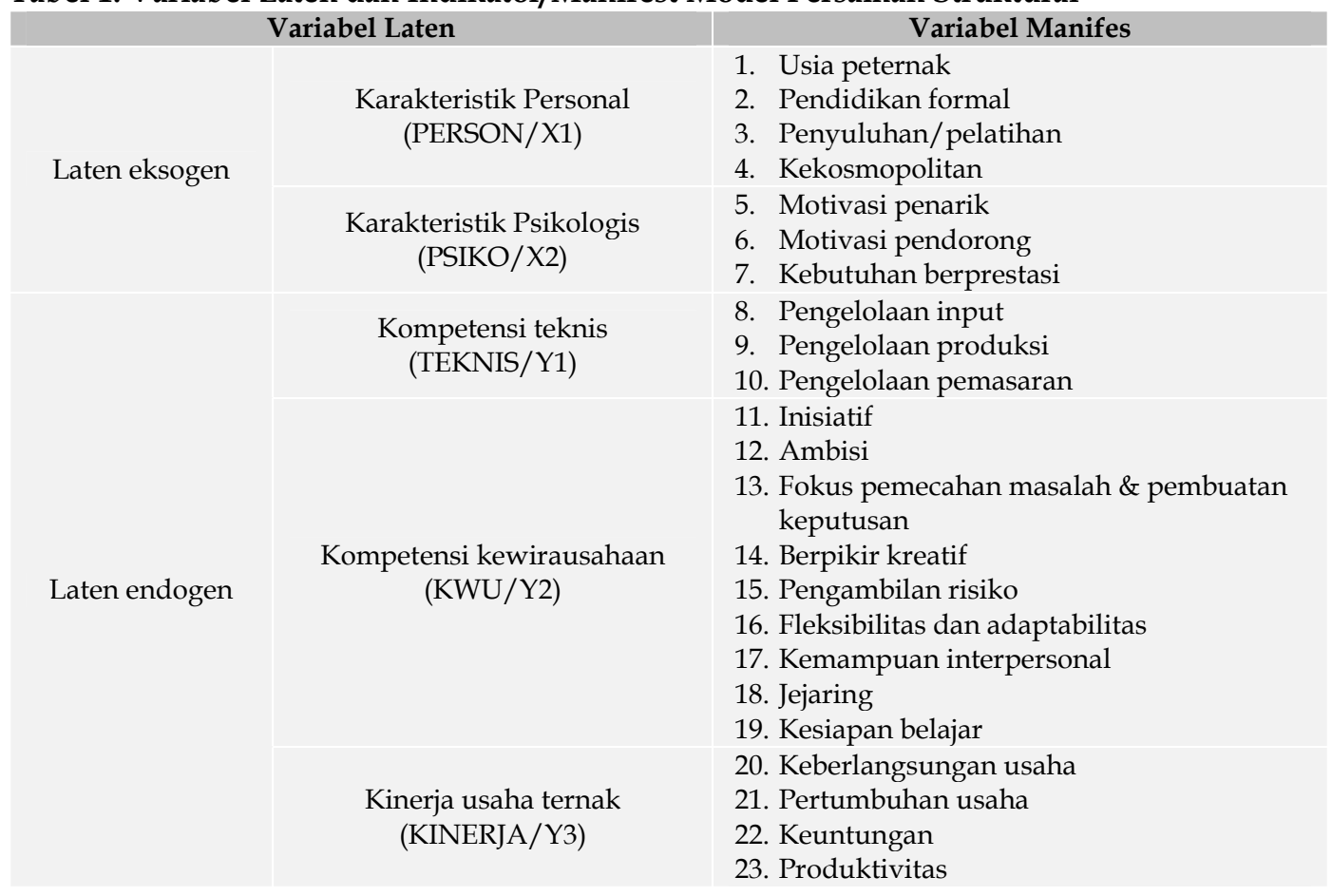




\section{IMPLEMENTASI MODEL STRUCTURAL EQUATION MODELING (SEM)}

Model SEM pada penelitian ini terdiri atas dua variabel laten eksogen, tiga variabel laten eksogen, dan 23 indikator. Variabel laten eksogen yaitu karakteristik personal dan psikologis peternak. Variabel laten endogen yaitu kompetensi teknis, kompetensi kewirausahaan, dan kinerja usaha. Indikator yaitu usia peternak, pendidikan formal, penyuluhan/pelatihan, kekosmopolitan, motivasi awal beternak (penarik dan pendorong), kebutuhan berprestasi, pengelolaan input, produksi, dan pemasaran, inisiatif, ambisi, fokus pada pemecahan masalah dan pembuatan keputusan, berpikir kreatif, pengambilan risiko, fleksibilitas dan adaptabilitas, kemampuan interpersonal, jejaring, kesiapan belajar, keberlangsungan dan pertumbuhan usaha, keuntungan, produktivitas. Hubungan antar variabel, serta model struktural dan model pengukurannya digambarkan dalam bentuk diagram lintas (path diagram) pada Gambar 2.

\section{HIPOTESIS PENELITIAN}

H1 : Karakteristik personal (X1) berpengaruh positif dan signifikan terhadap kompetensi teknis (Y1)

H2 : Karakteristik psikologis (X2) berpengaruh positif dan signifikan terhadap kompetensi teknis (Y1)
H3 : Karakteristik personal (X1) berpengaruh positif dan signifikan terhadap kompetensi kewirausahaan (Y2)

H4: Karakteristik psikologis (X2) berpengaruh positif dan signifikan terhadap kompetensi kewirausahaan (Y2)

H5 : Kompetensi teknis (Y1) berpengaruh positif dan signifikan terhadap kinerja usaha (Y3)

H6: Kompetensi kewirausahaan (Y2) berpengaruh positif dan signifikan terhadap kinerja usaha (Y3)

\section{HASIL DAN PEMBAHASAN}

\section{KARAKTERISTIK PETERNAK}

Tingkat karakteristik peternak terbagi menjadi 5 (lima) kategori karakteristik (1 = sangat rendah, $5=$ sangat tinggi). Karakteristik personal peternak sapi potong di Kabupaten Bandung dilihat dari usia, pendidikan formal dan informal, serta tingkat kekosmopolitan. Rata-rata usia peternak termasuk ke dalam kategori sedang dimana sebesar 50.41 persen berusia dewasa madya (usia 40-59). Rata-rata pendidikan formalnya termasuk kategori sangat rendah karena 86.78 persen hanya menempuh pendidikan tingkat SD. Rata-rata pendidikan informalnya pun termasuk kategori rendah karena 49.59 persen dari mereka belum pernah mengikuti penyuluhan.

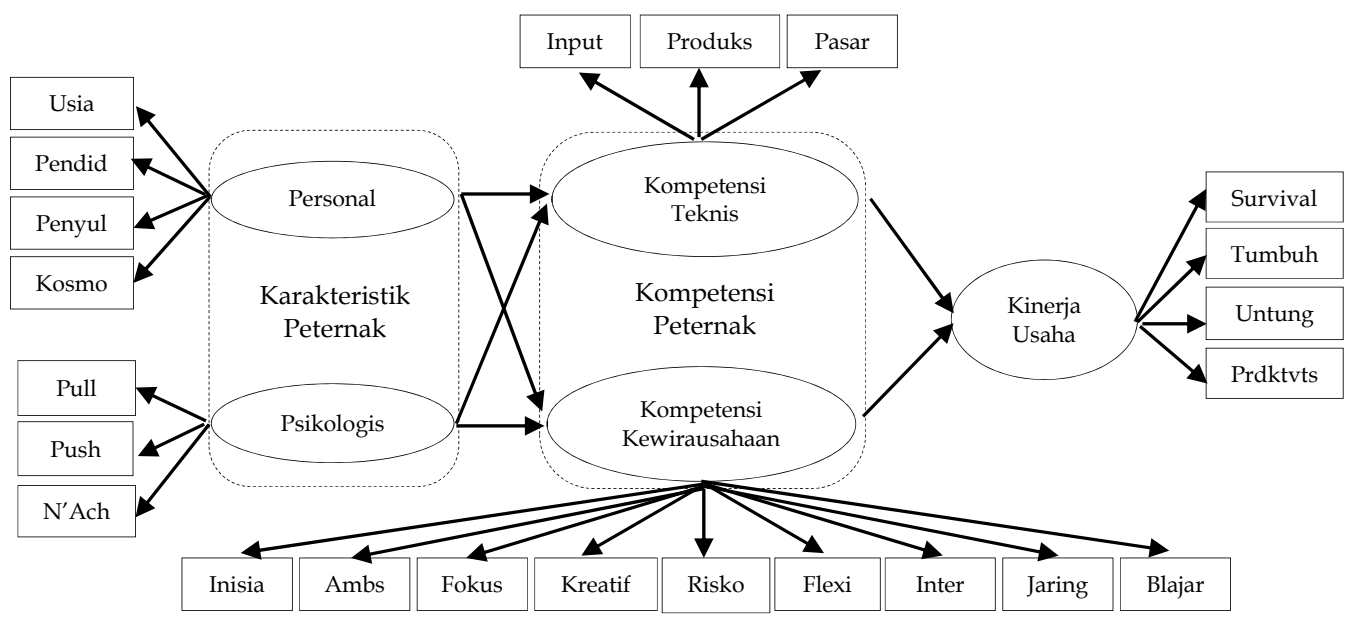

Gambar 2. Model Pengaruh Karakteristik Peternak melalui Kompetensi Peternak terhadap Kinerja Usaha Ternak Sapi Potong 
Tingkat kekosmopolitannya termasuk kategori sedang karena 56.20 persen dari mereka sudah mampu mengakses modal dari luar, yaitu investor (sistem maro) dan bank melalui bantuan KKPE (Kredit Ketahanan Pangan dan Energi), tetapi belum pernah mengakses informasi tetang usaha ternak selain antar peternak.

Karakteristik psikologis peternak, dilihat dari motivasi dan kebutuhan berprestasi ( $\mathrm{N}^{\prime}$ Ach), rata-rata termasuk kategori tinggi. Dalam penelitian ini, motivasi peternak dilihat dari keinginan pribadi (motivasi 1), usaha yang sangat menguntungkan (motivasi 2), dan tidak ada pilihan usaha lain (motivasi 3). Sebesar 71.90 persen peternak menyetujui bahwa beternak sapi potong merupakan keinginan mereka pribadi, sebesar 67.77 persen peternak menyetujui bahwa usaha ternak sapi potong sangat menguntungkan, dan 46.28 persen peternak menyetujui bahwa mereka beternak sapi arena tidak ada pilihan lain. Sementara itu, kebutuhan berprestasi dilihat dari keinginan kuat untuk lebih berhasil dari peternak lain ( $\mathrm{N}^{\prime}$ Ach 1$)$ dan keinginan kuat untuk lebih berkembang dari sekarang (N'Ach 2). Sebesar 57.02 persen ( $\mathrm{N}^{\prime}$ Ach 1) dan 61.98 persen ( $\mathrm{N}^{\prime}$ Ach 2) peternak menyetujui adanya keinginan tersebut.

Tabel 2. Rata-rata Tingkat Karakteristik Peternak

\begin{tabular}{|l|c|c|c|}
\hline \multicolumn{1}{|c|}{$\begin{array}{c}\text { Karakteristik } \\
\text { Peternak }\end{array}$} & $\begin{array}{c}\text { Rata2 } \\
\text { Skor }\end{array}$ & Kategori & $\begin{array}{c}\% \\
\text { tertinggi }\end{array}$ \\
\hline $\begin{array}{l}\text { Karakteristik personal: } \\
\text { 1. Usia }\end{array}$ & 2.82 & Sedang & 50.41 \\
\hline $\begin{array}{l}\text { 2. Pendidikan } \\
\text { formal }\end{array}$ & 1.20 & $\begin{array}{c}\text { Sangat } \\
\text { rendah }\end{array}$ & 86.78 \\
$\begin{array}{l}\text { 3. Pendidikan } \\
\text { informal }\end{array}$ & 2.31 & Rendah & 48.76 \\
\hline $\begin{array}{l}\text { 4. Kosmopolit } \\
\text { Karakeristik psikologis: }\end{array}$ & 3.15 & Sedang & 56.20 \\
\hline 1. Motivasi 1 & 4.18 & Tinggi & 71.90 \\
\hline 2. Motivasi 2 & 4.02 & Tinggi & 67.77 \\
\hline 3. Motivasi 3 & 3.27 & Sedang & 46.28 \\
\hline 4. N'Ach 1 & 4.02 & Tinggi & 57.02 \\
\hline 5. N'Ach 2 & 4.10 & Tinggi & 61.98 \\
\hline
\end{tabular}

\section{KOMPETENSI PETERNAK}

Tingkat kompetensi peternak pun terbagi ke dalam 5 kategori kompetensi $(1=$ sangat rendah, $5=$ sangat tinggi) dan seluruhnya sudah termasuk kategori tinggi. Kompetensi peternak sapi potong di Kabupaten Bandung dilihat dari kompetensi teknis dan kewirausahaan. Kompetensi teknis dilihat dari kemampuan mengelola input, produksi, dan pemasaran. Sementara kompetensi kewirausahaan dilihat dari inisiatif, ambisi, fokus pada penyelesaian masalah dan pengambilan keputusan, berpikir kreatif, pengambilan risiko, fleksibilitas dan adaptabilitas, kemampuan interpersonal, jejaring, dan kesiapan belajar.

\section{Tabel 3. Rata-rata Tingkat Kompetensi} Peternak

\begin{tabular}{l|c|c|}
\hline \multicolumn{1}{|c|}{ Kompetensi Peternak } & $\begin{array}{c}\text { Rataan } \\
\text { Skor }\end{array}$ & Kategori \\
\hline $\begin{array}{l}\text { Kompetensi teknis: } \\
\text { 1. Pengelolaan input }\end{array}$ & 3.69 & Tinggi \\
\hline $\begin{array}{l}\text { 2. Pengelolaan produksi } \\
\text { 3. Pengelolaan } \\
\text { pemasaran }\end{array}$ & 3.53 & Tinggi \\
\hline $\begin{array}{l}\text { Kompetensi kewirausahaan: } \\
\text { 1. Inisiatif }\end{array}$ & 3.78 & Tinggi \\
\hline $\begin{array}{l}\text { 2. Ambisi } \\
\text { 3. Fokus pada } \\
\text { penyelesaian masalah } \\
\text { dan pengambilan } \\
\text { keputusan }\end{array}$ & 3.98 & Tinggi \\
\hline $\begin{array}{l}\text { 4. Berpikir kreatif } \\
\text { 5. Pengambilan risiko }\end{array}$ & 3.91 & Tinggi \\
\hline $\begin{array}{l}\text { 6. Fleksibilitas dan } \\
\text { adaptabilitas }\end{array}$ & 3.83 & Tinggi \\
\hline $\begin{array}{l}\text { 7. Kemampuan } \\
\text { interpersonal }\end{array}$ & 3.83 & Tinggi \\
\hline $\begin{array}{l}\text { 8. Jejaring } \\
\text { 9. Kesiapan untuk } \\
\text { belajar }\end{array}$ & 4.17 & Tinggi \\
\hline
\end{tabular}

\section{KINERJA USAHA TERNAK}

Tingkat kinerja dalam penelitian ini adalah persepsi peternak mengenai kondisi usaha ternak mereka saat ini dibandingkan dengan kondisi usaha awal. Kinerja usaha dilihat dari keberlangsungan dan pertumbuhan usaha, profitabilitas, dan produktivitas. Tingkat kinerja usaha ternak terbagi ke dalam 5 kategori $(1=$ sangat rendah, $5=$ sangat tinggi).

Kinerja usaha ternak sapi potong di Kabupaten Bandung sudah termasuk kategori 
tinggi jika dilihat dari variabel keberlangsungan dan produktivitas usaha, tetapi dengan nilai rataan skor yang tidak terlalu tinggi. Hal ini karena sebesar 45.45 persen peternak menyatakan bahwa keberlangsungan usaha ternak mereka 'sama saja' dan 42.98 peternak menyatakan 'lebih tinggi' dibandingkan dengan kondisi awal usaha mereka. Sementara itu produktivitas usaha ternak, umumnya dilihat dari pertambahan bobot badan dan rata-rata jumlah ternak yang mati/sakit parah dalam 1 tahun. Sebanyak 52.07 persen peternak menyatakan bahwa produktivitasnya 'sama saja', sedangkan 39.67 persen menyatakan 'lebih tinggi' dibandingkan kondisi awal usaha.

Pertumbuhan usaha dilihat dari pertumbuhan jumlah ternak yang dimiliki dan profitabilitas dilihat dari pertumbuhan jumlah ternak dijual, keduanya termasuk kategori sedang. Sebanyak 38.02 persen peternak menyatakan pertumbuhan usahanya 'sama saja', sedangkan 39.67 persen menyatakan 'lebih tinggi' dibandingkan kondisi awal usaha. Sementara itu, 47.11 persen peternak menyatakan profitabilitasnya 'sama saja', sedangkan 34.71 persen peternak menyatakan profitabilitas usahanya yang sekarang 'lebih tinggi'.

\section{Tabel 4. Rata-rata Tingkat Kinerja Usaha Ternak}

\begin{tabular}{|l|c|c|}
\hline \multicolumn{1}{|c|}{ Kinerja Usaha } & Rataan & Kategori \\
\hline Kernak & Skor & \\
\hline Peberlangsungan & 3.46 & Tinggi \\
\hline Profitabuhan & 3.37 & Sedang \\
\hline Produktitas & 3.36 & Sedang \\
\hline
\end{tabular}

\section{ANALISIS SEM}

Analisis SEM digunakan untuk menganalisis pengaruh karakteristik peternak terhadap kinerja usaha ternak melalui kompetensi peternak sapi potong. Jadi, di sini dianalisis bagaimana pengaruh langsung antara kedua karakteristik terhadap kedua kompetensi dan pengaruh langsung antara kedua kompetensi terhadap kinerja usaha. Selain itu, dianalisis pula bagaimana pengaruh tidak langsung antara karakteristik terhadap kinerja.

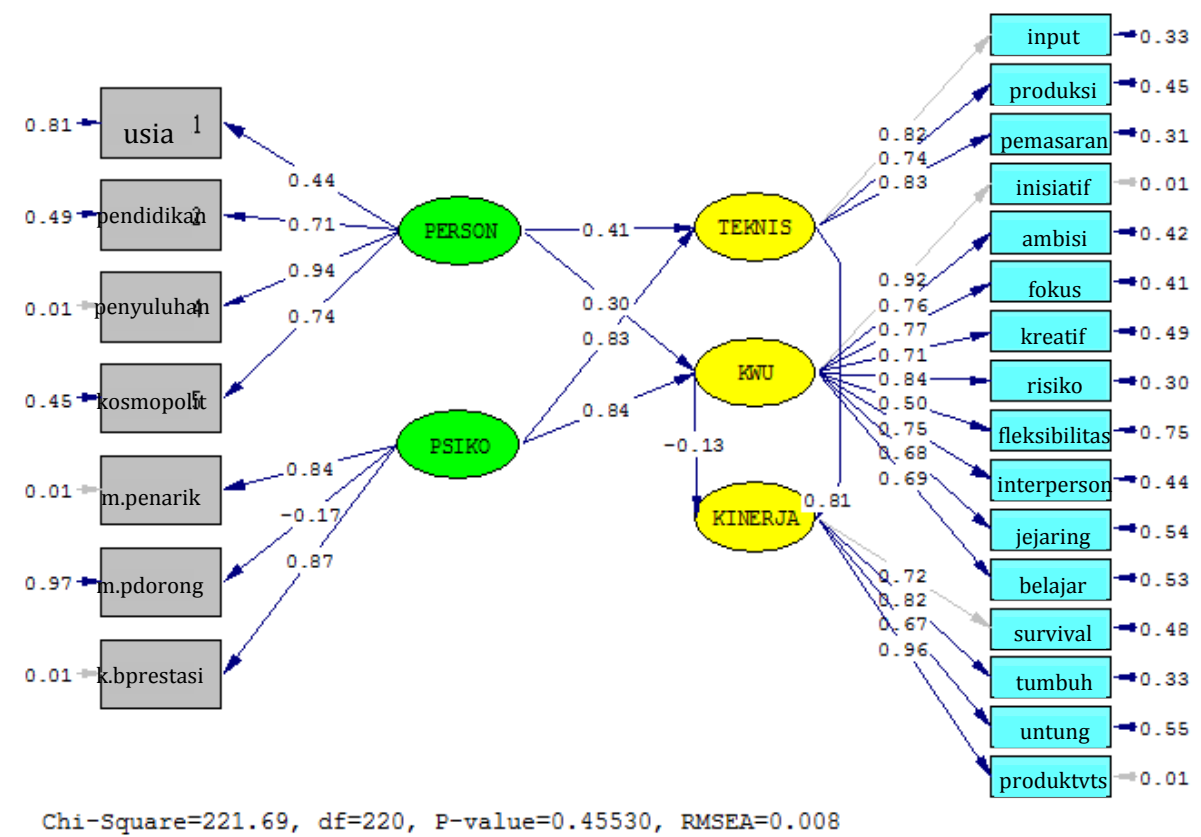

\section{Gambar 3. Model SEM (Estimasi Standardized Solution): Pengaruh Karakteristik Peternak melalui Kompetensi Peternak terhadap Kinerja Usaha Ternak Sapi Potong}




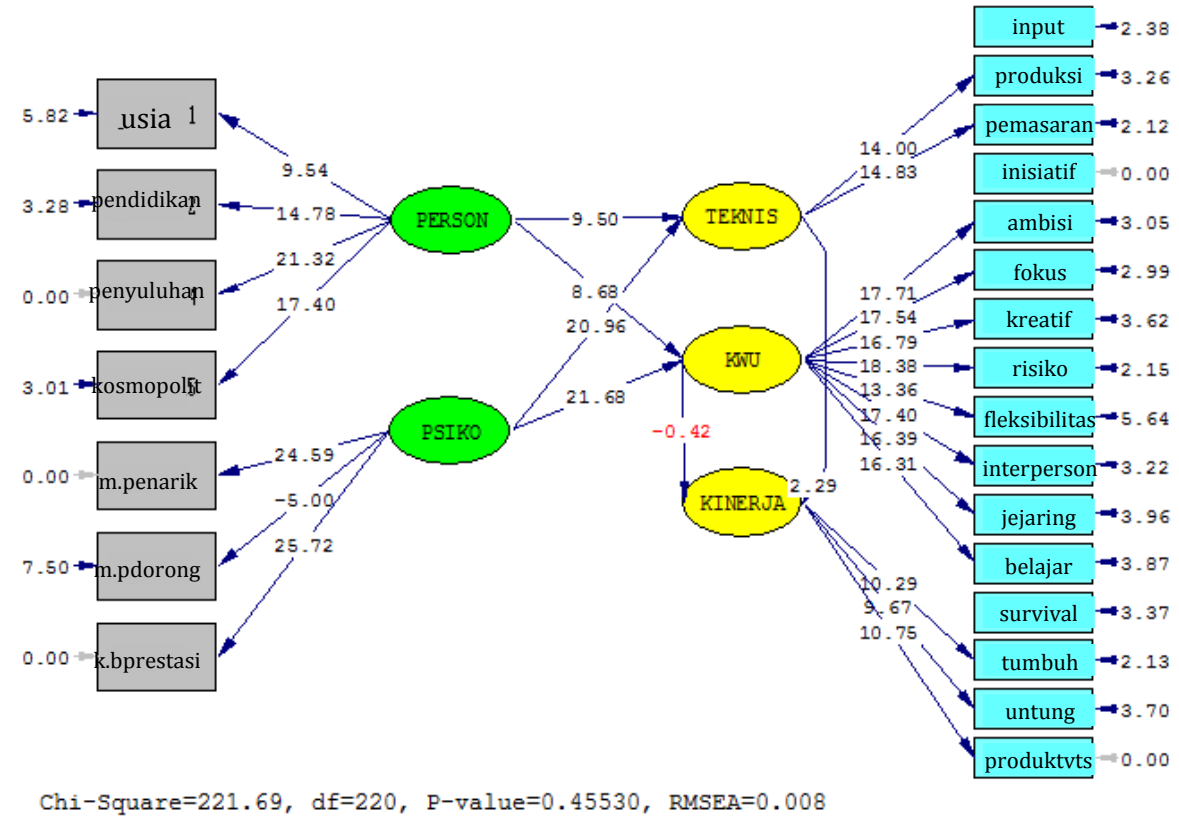

\section{Gambar 4. Model SEM (t-value): Pengaruh Karakteristik Peternak melalui Kompetensi Peternak terhadap Kinerja Usaha Ternak Sapi Potong}

Tabel 5 menggambarkan pengaruh langsung antar variabel laten dilihat dari besar nilai muatan faktor dan signifikansinya. Semua hubungan antar variabel menunjukkan hubungan yang positif. Dari tabel dapat diketahui bahwa ada 1 hubungan yang tidak signifikan, yaitu hubungan antara kompetensi kewirausahaan (Y2) dengan kinerja usaha (Y3). Hal ini berarti tinggi rendahnya kinerja usaha ternak sapi potong di Kabupaten Bandung tidak dipengaruhi oleh kompetensi kewirausahaan peternak. Namun, kompetensi teknis peternak berpengaruh positif dan signifikan terhadap kinerja usaha ternak.

Adapun kompetensi teknis lebih dipengaruhi oleh karakteristik psikologis (0.83) dibandingkan dengan karakteristik personal peternak (0.41). Begitupun dengan kompetensi kewirausahaan, lebih dipengaruhi oleh karakteristik psikologis (0.84) dibandingkan dengan karakteristik personal (0.30).

Sementara itu, Tabel 6 menjelaskan pengaruh tidak langsung karakteristik peternak terhadap kinerja usaha ternak, yaitu melalui kompetensi peternak. Dari tabel diketahui bahwa secara tidak langsung, karakteristik psikologis (0.56) peternak lebih berpengaruh terhadap kinerja usaha ternak dibandingkan dengan karakteristik personalnya (0.29).

Tabel 5. Pengaruh Langsung antara Karakteristik dan Kompetensi Peternak, serta Kinerja Usaha Ternak Sapi Potong

\begin{tabular}{|l|c|l|c|c|c|c|}
\hline \multicolumn{2}{|c|}{ Hubungan antar variabel laten } & Muatan faktor & t-hitung & Keterangan \\
\hline Karakteristik personal (X1) & $\rightarrow$ & Kompetensi teknis (Y1) & 0.41 & 9.50 & Signifikan \\
\hline Karakteristik psikologis (X2) & $\rightarrow$ & Kompetensi teknis (Y1) & 0.83 & 20.96 & Signifikan \\
\hline Karakteristik personal (X1) & $\rightarrow$ & $\begin{array}{l}\text { Kompetensi } \\
\text { kewirausahaan (Y2) }\end{array}$ & 0.30 & 8.68 & Signifikan \\
\hline Karakteristik psikologis (X2) & $\rightarrow$ & Kompetensi & & \\
Kompetensi teknis (Y1) & $\rightarrow$ & Kinerja usaha (Y3) & 0.84 & 21.68 & Signifikan \\
\hline Kompetensi kewirausahaan (Y2) & $\rightarrow$ & Kinerja usaha (Y3) & -0.13 & 2.29 & Signifikan \\
\hline
\end{tabular}

Keterangan : Jika t-hitung > t tabel 1.96, maka signifikan 
Tabel 6. Pengaruh Karakteristik Peternak Terhadap Kinerja Usaha Ternak melalui Kompetensi

\begin{tabular}{|l|c|c|c|}
\multirow{2}{*}{\multicolumn{1}{|c|}{ Variabel X }} & \multicolumn{3}{|c|}{ Pengaruh tidak langsung melalui } \\
\cline { 2 - 4 } & Kompetensi teknis (Y1) & Kompetensi kewirausahaan (Y2) & Total \\
\hline Karakteristik personal (X1) & 0.33 & -0.04 & 0.29 \\
\hline Karakteristik psikologis (X2) & 0.67 & -0.11 & 0.56 \\
\hline
\end{tabular}

Pengaruh terbesar adalah melalui kompetensi teknis dengan pengaruh positif. Jadi, untuk meningkatkan kinerja usaha dapat dilakukan dengan cara meningkatkan kompetensi teknis peternak, dan kompetensi teknis ini dapat ditingkatkan dengan cara meningkatkan karakteristik psikologis peternak, khususnya motivasi dan kebutuhan berprestasi peternak.

Dari model SEM pada Gambar 3 dapat diketahui indikator apa saja yang memiliki kontribusi terbesar yang menjelaskan masingmasing variabel laten, dilihat dari nilai muatan faktornya. Kontributor terbesar untuk variabel karakteristik personal (X1) adalah pendidikan informal dengan nilai muatan faktor sebesar 0.94. Kontributor terbesar untuk variabel karakterstik psikologis (X2) adalah kebutuhan berprestasi dengan nilai muatan faktor sebesar 0.87. Kontributor terbesar untuk variabel kompetensi teknis (Y1) adalah pengelolaan pemasaran dengan nilai muatan faktor sebesar 0.83 . Kontributor terbesar untuk variabel kompetensi kewirausahaan (Y2) adalah inisiatif dengan nilai muatan faktor sebesar 0.92. Kontributor terbesar untuk variabel kinerja usaha (Y3) adalah produktivitas dengan nilai muatan faktor sebesar 0.96 .

\section{KESIMPULAN DAN SARAN KESIMPULAN}

Hasil penelitian menunjukkan bahwa peternak sapi potong di Kabupaten Bandung memiliki tingkat karakteristik personal yang bervariatif di setiap indikatornya. Rata-rata peternak berusia dewasa madya (40-59 tahun), berpendidikan sangat rendah (SD), belum pernah ikut penyuluhan, dan memiliki tingkat kekosmopolitan sedang karena sudah mampu mengakses modal dari investor (sistem maro) dan bank (bantuan kredit dari pemerintah), tetapi belum mengakses infomasi tentang usaha ternak selain dari sesama peternak. Sementara tingkat karakteristik psikologis peternak sudah termasuk ke dalam kategori tinggi, dilihat dari motivasi dan kebutuhan berprestasinya. Kompetensi teknis dan kompetensi kewirausahaan peternak juga sudah termasuk ke dalam kategori tinggi.

Hasil analisis SEM menunjukkan bahwa kedua karakteristik peternak berpengaruh positif dan signifikan terhadap kedua kompetensi, serta berpengaruh tidak langsung terhadap kinerja usaha, yaitu melalui kompetensi teknis. Karakteristik psikologis (kebutuhan berprestasi sebagai kontributor terbesar) lebih berpengaruh terhadap kompetensi dibandingkan dengan karakteristik personal (pendidikan informal sebagai kontributor terbesar). Kompetensi teknis (mengelola pemasaran dan input sebagai kontributor terbesar) berpengaruh positif (0.81) dan signifikan terhadap kinerja usaha (produktivitas sebagai kontributor terbesar), sedangkan kompetensi kewirausa-haan tidak berpengaruh. Secara tidak langsung, karakteristik psikologis (0.56) lebih berpengaruh terhadap kinerja usaha dibandingkan karakteristik personal (0.29).

\section{SARAN}

Implikasinya, produktivitas sapi potong dapat ditingkatkan dengan cara meningkatkan kompetensi teknis, khususnya dalam mengelola pemasaran dan input. Kompetensi ini dapat ditingkatkan dengan cara meningkatkan kebutuhan berprestasi dan partisipasi aktif peternak dalam mengikuti penyuluhan/pelatihan, misalnya melalui penghargaan. 


\section{DAFTAR PUSTAKA}

Alma B. 2010. Kewirausahaan Untuk Mahasiswa dan Umum. Bandung : Alfabeta.

Amit R, Muller E. 1995. Push and pull entrepreneurship (two types based on motivation). Journal of Small Business and Entrepreneurship. Vol. 12, No. 4, 64-80.

Bergevoet, RHM. 2005. Entrepreneurship of Dutch Dairy Farmers. [Disertasi]. Wageningen University. Wageningen (NL).

Bird B. 1995. Toward a Theory of Entrepereneurial Competency. Connecticut (US): Jai Press.

1996. Entrepreneurial Behavior. Singapore: Irwin Mc Graw Hill.

Chandler GN, Hanks SH. 1994. Founder competence, the environment, and venture performance. Entrepreneurship: Theory and Practice. Vol. 18, No. 3, 77-89.

Direktorat Pangan dan Pertanian. 2013. Studi Pendahuluan: Rencana Pembangunan Jangka Menengah Nasional (RPJMN) Bidang Pangan dan Pertanian 20152019. Badan Perencanaan Pembangunan Nasional (BAPPENAS).

[Disnak] Dinas Peternakan Provinsi Jawa Barat. 2009. Statistik Peternakan. Pemerintah Provinsi Jawa Barat.

2013. Statistik Peternakan. Pemerintah Provinsi Jawa Barat.

Griffin RW. 2004. Manajemen. Edisi 7. Jilid 1. Jakarta: Erlangga.

Inggarwati K, Kaudin A. 2010. Peranan Faktor-faktor Individu dalam Mengembangkan Usaha: Studi Kuantitatif pada Wirausaha Kecil di Salatiga. Jurnal Manajemen Bisnis. Vol. 3, No. 2 (2010), 185-202.

Jauch LR, Glueck WF. 1998. Business Policy and Strategic Management. McGraw Hill Books Company, Singapore.
Kahan, David. 2012. Entrepreneurship in Farming. Rome: Food and Agriculture Organization of the United Nations (FAO).

Kartasapoetra AG. 1987. Teknologi Penyuluhan Pertanian. Jakarta: Bina Aksara.

[Kementan] Kementrian Pertanian Republik Indonesia. 2010. Peraturan Menteri Pertanian Nomor: 19/Permentan/ OT.140/2/2010 tentang Pedoman Umum Program Swasembada Daging Sapi 2014.

Lerner M, Almor T. 2002. Relationships among strategic capabilities and the performance of women-owned amall ventures. Journal of Small Business Management. Vol. 40, No. 2, 109-125.

Lionberger HF. 1960. Adoption of New Ideas and Practice. Ames, Iowa: The Iowa State University Press.

Lionberger HF, Gwin H. 1982. Communication Strategies: A Guide for Agricultural Change Agents. Danville: The Interstate Printers and Publisher, Inc.

Man T, Lau T, Chan KF. 2002. The competitiveness of small and medium enterprises. A conceptualization with focus on entrepreneurial competencies. Journal of Business Venturing. Vol. 17, No. 2, 123-142.

Moeheriono. 2009. Pengukuran Kinerja Berbasis Kompetensi. Jakarta : Ghalia Indonesia.

Padmowihardjo S. 1978. Beberapa Konsepsi Proses Belajar dan Implikasinya. [Makalah]. Institut Pendidikan Latihan dan Penyuluhan Pertanian Ciawi. Bogor.

Praag CM. 2005. Successful Entrepreneurship. Cheltenham (GB): $\quad$ Edward Elgar Publishing Limited.

Riyanti BPD. 2003. Kewirausahaan dari Sudut Pandang Psikologi Kepribadian. Jakarta: PT. Grasindo (Gramedia Widiasarana Indonesia). 
Salman DM, Badr K. 2011. Linking Entrepreneurship and Total Factor Productivity What are the Economic Setting Required. Prodising Seminar Internasional Politics and Eonomic Development 20-22 Maret 2011. Turki : Economic Research Forum.

Sorensen JB, Chang PMY. 2006. Determinants of Succesfull Entrepreneurship : A Review of the Recent Literature. MIT Sloan School of Management. Cambridge.

Spencer LM, Spencer SM. 1993. Competence Work: Model for Superior Performance. John Wiley and Sons, Inc.

Sumardjo. 1999. Transformasi Model Penyuluhan Pertanian Menuju Pengembangan Kemandirian Petani (Kasus di Propinsi Jawa Barat). [Disertasi]. Program Pascasarjana Institut Pertanian Bogor. Bogor.

Suryana. 2013. Kewirausahaan : Kiat dan Proses Menuju Sukses. Edisi 4. Jakarta: Salemba Empat.

Zimmerer TW, Scarborough N. 1996. Entrepreneurship the New Venture Formation. Prenice-Hall International, Inc. 
Lampiran 1. Hasil Uji Kecocokan (Goodness Of Fit)

\begin{tabular}{|c|c|c|c|}
\hline $\begin{array}{l}\text { Ukuran GOF } \\
\text { (Goodness-of-Fit) }\end{array}$ & Tingkat Kecocokan & Hasil & Ket \\
\hline $\begin{array}{l}\text { Chi-Square }\left(\chi^{2}\right) \\
\text { P-value }\end{array}$ & $\begin{array}{l}\text { Nilai yang kecil } \\
\quad P \geq 0.05\end{array}$ & $\begin{array}{c}\chi^{2}=221.69 \\
P=0.46\end{array}$ & Good Fit \\
\hline $\begin{array}{l}\text { Non-centrality Parameter (NCP) } \\
\text { Interval }\end{array}$ & $\begin{array}{l}\text { Nilai yang kecil } \\
\text { Interval yang sempit }\end{array}$ & $\begin{array}{l}\mathrm{NCP}=1.69 \\
(0.00 ; 40.75)\end{array}$ & Good Fit \\
\hline $\begin{array}{l}\text { Root Mean Square Error of } \\
\text { Approximation (RMSEA) }\end{array}$ & $0.05<$ RMSEA $\leq 0.08$ & RMSEA $=0.008$ & Close Fit \\
\hline Expected Cross-Validation Index (ECVI) & $\begin{array}{l}\text { Nilai yang kecil dan dekat } \\
\text { dengan ECVI saturated }\end{array}$ & $\begin{array}{c}\mathrm{ECVI}=2.78 \\
(\mathrm{~S}=4.60 ; \mathrm{I}=50.28)\end{array}$ & Good Fit \\
\hline Akaike Information Criterion (AIC) & $\begin{array}{l}\text { Nilai yang kecil dan dekat } \\
\text { dengan AIC saturated }\end{array}$ & $\begin{array}{c}\mathrm{AIC}=333.69 \\
(\mathrm{~S}=552.00 ; \mathrm{I}=6033.69)\end{array}$ & Good Fit \\
\hline $\begin{array}{l}\text { Consistent Akaike Information Criterion } \\
\text { (CAIC) }\end{array}$ & $\begin{array}{l}\text { Nilai yang kecil dan dekat } \\
\text { dengan CAIC saturated }\end{array}$ & $\begin{array}{c}\mathrm{CAIC}=546.26 \\
(\mathrm{~S}=1599.64 ; \mathrm{I}=6121.00)\end{array}$ & Good Fit \\
\hline Normed Fit Index (NFI) & $\geq 0.90$ & 1.00 & Good Fit \\
\hline Non-Normed Fit Index (NNFI) & $\geq 0.90$ & 1.04 & Good Fit \\
\hline Comparative Fit Index (CFI) & $\geq 0.90$ & 1.00 & Good Fit \\
\hline Incremental Fit Index (IFI) & $\geq 0.90$ & 1.04 & Good Fit \\
\hline Relative Fit Index (RFI) & $\geq 0.90$ & 1.00 & Good Fit \\
\hline Root Mean Square Residual (RMR) & $\leq 0.05$ atau $\leq 0.1$ & 0.084 & Good Fit \\
\hline Goodness of Fit Index (GFI) & $\geq 0.90$ & 0.97 & Good Fit \\
\hline Adjusted Goodness of Fit Index (AGFI) & $\geq 0.90$ & 0.96 & Good Fit \\
\hline
\end{tabular}


